\title{
Awareness and Perspectives Social Media as New Strategic Marketing Approach in Minor Industries; Notion grounded on AIDA Model
}

\author{
Roohi Mumtaz \\ Assistant Professor, \\ Alfalah University, Dubai, UAE
}

\begin{abstract}
Business owners and entrepreneurs throughout the world apply the AIDA model widely and extensively. Though, the awareness of the strategic application of this model for social media is hardly known by the cottage and minor business owners of undeveloped nations. Therefore the main aim of this paper is to provide awareness of the strategic application of AIDA model to those unprivileged business owners and entrepreneurs who are running their minor businesses with great difficulties in the unprivileged areas of Pakistan. The focus group and personal interviews were conducted to collect the information. The outcome shows that the trend of applying the AIDA model for marketing and promoting products and services through social media is widely used around the globe and the percentage shows a considerable increase in this respect. However, the minor business owners and entrepreneurs of the unprivileged areas of Pakistan still not utilizing the AIDA model strategically and believing in approaching their customers traditionally.
\end{abstract}

Keywords: Minor Business; Entrepreneurs' Social Media; Marketing, AIDA Model; Strategy; Awareness Perspective

\section{Introduction}

The popularity of social media is not new. It became very popular among people of all ages around the world however the way of utilizing it varied from person to person and needs to needs. These days' social media became a new marketing platform for small and medium-range businesses and the competitive marketing strategies apply here as well. The extent to which these strategies are effective and beneficial for the companies and businesses is remained ambiguous. The literature about the impact of utilizing social media as marketing instruments for promoting products and services by small business companies is also not available in great quantity. The marketing intellectuals and senior professionals of the marketing field know that the AIDA model has vast applicability in marketing practices and activities either based on orthodox approaches or online methods. The study of this research paper will investigate and provide the ways of using social media as one of the marketing instruments strategically to minor organizations based on the AIDA concept.

The phenomenon of using social media as a marketing instrument in Malaysia, Thailand Singapore, India, Bangladesh, and Pakistan is not new and big companies and medium-size companies are using social media as their effective marketing tool. Similarly, the large business companies in Malaysia are using different social media as marketing tools for promotion and services (shahizan et al. 2012). In contrast small and many medium-size business companies have not been utilizing the social media activity as their key marketing tools. Approximately, less than 20 percent of small companies using social networking sites to promote and advertise their products and services in Malaysia (shahizan et al. 2012). However, the percentage of using social networking sites for businesses has far more increased nowadays. On the other hand, these companies are the backbone of the Malaysian economy and responsible of providing job opportunities to the community.

Huge challenges for the entrepreneurs, cottage and minor organizations to market their services and products. They also face constraints of financial resources that also limit their chances to grow and compete with large and established organizations. The cottage and minor size companies face problems of not only they have limited resources but also because they hardly have any marketing manager that can strategically develop and execute plans for them to promote and excel (Berthon, Ewing, \& Napoli, 
2008; Moss, Ashford, \& Shani, 2003; Gilmore et al., 2001). These companies faced typical issues in marketing arena (Huang and Brown 1999). The only option they have to overcome the challenges is the usage of social networking sites. These sites allow entrepreneurs, cottage industries and minor business owners to use the medium for disseminating the salient features of products and services and give a boost to their businesses. However, it has been noted through the studies conducted by the group of small and medium-sized enterprises that minor businesses do not have any plans or strategies to properly utilize the social networking sites (Khan, Hatami, Sasidharan, \& Al-Roshdi, 2017). Therefore the chances of success become more infinitesimal and uncertain if these companies do not develop or set standards for marketing. The primetime anytime program which is introduced by Facebook for free. This nod seems like just the television prime time. These resource centers contain tutorials and videos to provide the marketing and promotional insights and solutions to business people who wanted to build their brand name and understand the digital marketing concept through social media (Small Business Trends, 2018).

In businesses these days, the AIDA model plays important role in formulating the strategies related to the marketing field. The main focus of this communication model is the individual's transactions and purchases they executed. The prominence is usually given to the credit of goods or services. Three key stages of communications are involved in digital marketing; create the existence of goods and services, increasing good relationships and importance given to consumers (Rowley, 2002). Social media is not only a source of attracting potential customers if used optimistically, but it can also provide an efficient e-commerce platform for small business owners and entrepreneurs (Small Business Trends, 2018) and in this situation, AIDA model fits well in the digital marketing context.

There are huge gaps present with respect to the cottage and minor businesses using social media strategically in Pakistan. Therefore this study is timely to give awareness to those people who are unaware of the strength of social media and using the medium strategically and can raise their earnings and profits for better living standards and prosperous life and giving value to the customer (Rowley, 2002). It has been suggested through prior debate that social networking sites have been utilizing comprehensively as a publicizing instrument by the huge businesses organizations. On the contrary, minor and many medium-size organizations are still struggling to utilize it up to its maximum limit. They are still in its infancy. Moreover, there are few and very scarce research conducted on the utilizing social networking sites strategically as publicizing tools by minor companies and cottage industries in perspective of Pakistan. Developing plans for utilizing social sites as publicizing instruments in minor size organizations and cottage industries will potentially decrease this applied gap. In a theoretical view, people know that in developing marketing strategies like sponsorships, promotions, advertising, etc. AIDA model is applied widely. Though it is still unclear in studies that how the AIDA model can be used and applied in minor businesses and is worthy to be investigated and researched.

In light of the above discussion, the key focus of this paper is to respond regarding "the use of social media as marketing tool, and what would be the appropriate strategy for cottage and minor businesses in Pakistan." Therefore the key aim of this research lied on AIDA model to progress and recommend a strategy for using social networking sites as advertising instrument for cottage and minor industries in Pakistan therefore; only cottage industries and minor businesses will be covered and benefited through the scope of this study. Moreover this study will open doors for other researchers to conduct in-depth studies on the similar topics with other contextual variables while taking varied and diverse societies of the world having similar demographic issues and challenges.

\section{Literature Review}

\section{Marketing, Publicizing and Promotion through Social Networking Sites:}

The word marketing is not new to the business world. This has been used to advertise and promote the products or services everywhere. However, the use of the medium and means are changing with the change of perceptions, demands, and approaches of people around the world. The development of marketing 
communications from print to electronic and from electronic to social media in cyberspace give them enough opportunity to shop online through various online shopping websites. Consumers have a great opportunity to shop online but also gain info and online materials while using social networking sites. They can easily make decisions before making any purchases. The trend shows that customers trust their social media contacts and friends on the advertisements exhibited by commercial companies (Woodcock \& Green, 2010). Business organizations use strategies and instruments to bring significant changes through social media and disseminate information regarding their services or products. The studies of Mangold and Faulds, (2009), state that marketing through social networking sites is the combination of oldstyle features and aspects used by business organizations. They use IMC (integrated marketing instruments) to converse with the consumers. In word of mouth, the consumers talk about each other experiences and in this scenario, the advertising managers have no command over the content of certain info and materials.

There are attractive forums present on social media where the interaction with different people is very easy and simple. People share their experiences, share videos, related jokes, comments, etc. these sharing of information, experiences, videos, and jokes play a vital role in building perceptions of the customers and consumers towards products or services. The shared information thus has great impact on product presentation, performance and building up branding (Woodcock \& Green, 2010). Various types and sizes of organizations used social media instruments as marketing instruments (Birkner, 2011). As compared to other communication instruments, social media provide consumers and customers the right opportunity to shop for cost-effective products with great efficiency. This allows social media to break the monopoly of larger business organizations and give equal opportunity to the medium and minor organizations to flourish (Kaplan \& Haenlein, 2010).

Moreover, social media websites (Facebook, Twitter, LinkedIn, etc.) provide opportunities to their users to interact and follow their favorite brands, business societies, and communities forums where consumers directly interact with them about the product or services (Reyneke, Pitt, \& Berthon, 2011). The loyal customers and consumers of specific brands also aid commercial companies to set up novel businesses and encourage them as well. Their comments, blogs, tweets and reviewing comments and so on also play a vital role in enhancing the growth and popularizing their products or services through word-of-mouth promoting techniques. These techniques are very important and valuable for minor businesses to make ground for their products and services. The organizations keep on checking and get feedbacks through blogs, tweets, comments on their social media page about their products or services (Reyneke, Pitt, \& Berthon, 2011). These activities help them to improve their services and the quality of their products. Relations with consumers and customers provide chances to the small organizations to utilize social networking sites as the best instrumental option for promoting and advertising plans (Reyneke et al., 2011). Though many minor organizations still struggling and trying hard to approach their targeted consumers and customers efficiently (Small Business Trends, 2011). Several of them are still not aware of the scope and potential of social networking sites in publicizing and promoting businesses.

According to the studies conducted by the Khan, et al. 2017, concluded that out of five small business organizations only one do not have plans and strategies to use social media as marketing instruments. Proper plans and marketing strategies play a vital role to ensure the effectiveness of using social networking sites (Khan, et al. 2017). Business people, who wanted to build their brand name and understand the digital marketing concept through social media, need to apply some strategy to flourish more (SMB Group, 2018) and AIDA model can play an important role in formulating strategies for small businesses and entrepreneurs etc. to attract the customers and enhanced online shopping through social media (Small Business Trends, 2018). These days approximately $80 \%$ of the people associated with small businesses use Facebook for marketing and promotional strategies and one of the most popular medium and marketing instrument in the digital world today (Small Business Trends, 2018). Social media is not only a source of 
attracting potential customers if used optimistically, it can also provide an efficient e-commerce platform for small business owners and entrepreneurs (Small Business Trends, 2018) and in this situation, the AIDA model fits well in digital marketing context.

\section{Social networking, marketing, and preceding researches}

Around 3000 marketing managers were included in a survey study of social networking sites and their use for the purposes of marketing and growth of businesses by Stelzner, (2013). The research covered the areas related to the types of social networking, their advantages when used as marketing tools, time allocation, most popular social sites among folks around the globe for marketing and managers wanted to learn the usage of social medium. The research concluded that approx. ninety-seven percent of the participants using social sites to publicize products and services. Approximately eighty-six percent of participants agreed that social media play important part in the growth and expansion of trade \& industries.

Moreover, around eighty-eight percent of managers are keen to recognize the best and efficient technique to attach to their consumers and customers. Whereas sixty-nine percent of managers think and wanted to make plans to maximize the use of YouTube more. It was also revealed from the studies that only minimal numbers of managers involved in using podcasting and that are only five percent (Stelzner, 2013). The most popular social networking sites selected by the managers were LinkedIn and Facebook. Among these 49 percent of managers choose Facebook as the most effective channel to advertise whereas only 16 percent of marketing managers voted in favor of LinkedIn. It is also revealed during the study that most of the marketing managers doubted that Facebook is effective for marketing products or services. The study further concluded that marketing managers would like to know more about the main problems including the use of appropriate strategy in order to encourage their goods or amenities through social media and that supports the notion of this study.

In the studies of Kirtis and Karahan, 2011 it has been said that during world economic and financial recession social networking sites emerged as cost-effective strategies tools for marketing and advertising. The use of social networking sites for disseminating business services or product information to consumers and customers is quick and rapid. In a short period of time, the business can be expanded beyond boundaries around the world. Another set of researchers scrutinized the usage of social sites in extravagance fashionable brands and explain ways to improve the equity of customers in business (Kim and Ko, 2011). It was revealed that social networking sites play role in advertising by exerting impact on customers and consumers equity so that they can incline to spend money to purchase. These are the important development in order to build or enhance customer's equities towards any brand. It became possible because of three main reasons;

a) Being a publicizing tool social site is the most popular and effective channel for organizations to publicize goods and facilities, b) marketing with the help of social networking sites are cost-effective, c) Client and brand parity can be established and upgraded by publicizing and advertising.

\section{Commercial Marketing and the Application of the AIDA Model}

In 1898, AIDA model theory which is also known as the theory of communication was suggested by E. St. Elmo Lewis. Attention, Interest, Desire, and action is the full version of the AIDA acronym. The theoretical basis was established after the life protection business research which explains the basic reasoning phases which are four in total. These reasoning phases were the experience of a person who got a new notion or to purchase a product (Michaelson \& Stacks, 2011). The researchers Barry and Howard explained the AIDA model as a quadrant stage method (Heath and Feldwick 2007). Initially, customer give attention then attracts with interest then generating desire and in the end, takes action to purchase. This four-step model is effective in assessing the marketing impact by regulating each step of mental conversion. This psychological transformation starts from viewing the ad till purchase being made (Kojima et al., 2010). The principle of the AIDA concept is still intact and is still pertinent despite the model was introduced 
centuries ago. In spite of today's communicative and collaborative world of internet and developing social networking sites, the consumers continually anxious to gain complete knowledge about the products or services they are interested in. On the basis of the information, they get about the products/ services benefits and show prompt desire to get those by fulfilling the criteria of necessities, requirements, and interests in order to buy or adopt other options for the same (Michaelson \& Stacks, 2011).

AIDA framework is applied to other products or services and to the online facilities too (Ashcroft and Hoey, 2001). AIDA model has various stages to fulfill the complete action. When the users exert their attention towards any goods or services, the reasoning stage is achieved. This is the first stage of the process of communiqué. In this process, the customers and consumers are looking for the existence of the products/ services. Secondly, there is a level of affective where the customers and consumers show their interest in a product/service offered. In search to have the answer to what has been offered. This kind of interest leads toward in order to buy the good or avail the facility. This leads to the level of behavior in which action is completed and customers and consumers utilize this service as an esteemed resource. The steps taken during the process of purchasing lied on the AIDA model were the outlined values and were referred by the respondents. Another researcher examined in his study that in online marketing, the factor of capturing the attention is somewhat weak Lagrosen (2005). As in traditional advertising and marketing, customers visit the web pages of the companies intentionally when browsing the internet and are very much minimal now. This type of problematic issue can be resolved by putting banners on dominant social sites and can search through links of any pertinent portal. The strong feature of online advertising and promotion is creating interest in consumers towards it. When the potential consumers browse the website of any organization, they get all the related information and get attracted to the promotions and offers on the products and services.

Furthermore, companies need to update and add new things continuously for those customers who visit the website regularly.
Explanation of product and services need to be provided to generate desire in customers to purchase online. In the final phase of action where customers need to make purchases and payments through an assimilated card system, online marketing, and promotional strategies are very helpful and supportive in whole of the process and so on. For generating awareness and drawing the attention of customers towards products and services advertising also play a vital role to spark desire and interest before their minds and attitude trigger to take actions for purchases (Hoek and Gendall, 2003). Attention acquired by the AIDA framework by putting its variants on the manuscript of advertising permits it to apply on sponsorship activities as well. In earlier literature, it has been steadily discussed that as marketing activities, the usage of the AIDA concept is extensive in advertising as either traditional approaches or online. Though there are hardly any studies conducted that views the AIDA model application in the perspective of publicizing and promoting goods or services through social media by minor business owners. This research therefore acclimatizes the model to outfit certain promotional and marketing strategies for the usage of social networking sites.

\section{Methods:}

\section{Approaches to Methodology}

This study aims to conduct complete and descriptive research of how strategically social networking sites can be utilized to market products and services. In order to explore the topic, a qualitative research method was used. This kind of extensive description with respect to social media cannot be attained by quantitative research (Taylor and Bogdan 1998). The use of social media and the instruments which were used by the minor business people and the situations they might come across is complex and to give the indepth description of these complex situations, use of appropriate methodology will give a manuscript of metaphors that involve individuals and their familiarities (Keegan, 2009). In order to collect data and information for developing strategies, this study used focus group and personal interviews to attain the required information. 


\section{Research Outline:}

To provide clarity to the research study and ensure that the methodology adopted here attains the desired outcome, a clear description of the research outline is given below in table \# 1:

Table \#1: Research Outline:

\begin{tabular}{|c|c|c|c|}
\hline $\begin{array}{l}\text { Research } \\
\text { Question }\end{array}$ & $\begin{array}{l}\text { Researc } \\
\text { h Aim }\end{array}$ & $\begin{array}{l}\text { Research } \\
\text { Methodol } \\
\text { ogy }\end{array}$ & $\begin{array}{l}\text { Research } \\
\text { Outcome }\end{array}$ \\
\hline $\begin{array}{l}\text { What is } \\
\text { the } \\
\text { suitable } \\
\text { strategy } \\
\text { in order } \\
\text { to } \\
\text { provide } \\
\text { awarenes } \\
\text { s of using } \\
\text { social } \\
\text { media as } \\
\text { promotio } \\
\text { nal } \\
\text { instrume } \\
\text { nt in } \\
\text { minor } \\
\text { industry? }\end{array}$ & $\begin{array}{l}\text { Develop } \\
\text { a } \\
\text { strategy } \\
\text { to } \\
\text { provide } \\
\text { awarene } \\
\text { ss in } \\
\text { order to } \\
\text { use } \\
\text { social } \\
\text { media as } \\
\text { marketi } \\
\text { ng } \\
\text { strategy } \\
\text { in minor } \\
\text { industri } \\
\text { es based } \\
\text { on the } \\
\text { concept } \\
\text { of } \\
\text { strategic } \\
\text { applicati } \\
\text { on of } \\
\text { AIDA } \\
\text { model }\end{array}$ & $\begin{array}{l}\text { Focus } \\
\text { group and } \\
\text { personal } \\
\text { interviews }\end{array}$ & $\begin{array}{l}\text { Strategy } \\
\text { to } \\
\text { provide } \\
\text { awarenes } \\
\mathrm{s} \text { for } \\
\text { using } \\
\text { social } \\
\text { networki } \\
\text { ng sites } \\
\text { as } \\
\text { promotio } \\
\text { nal } \\
\text { instrume } \\
\text { nt by } \\
\text { minor } \\
\text { industrie } \\
\mathrm{s}\end{array}$ \\
\hline
\end{tabular}

Source: Author

The research study divided into three different stages on the basis of the mapping of research. Those three stages are literature examination, focus-group discussions, and personal interviews and strategy development. To cover all the three stages, the research outline was developed and this outline linked the three stages of research with the theory used, results and aim. The analysis of literature gives the awareness of the area of computeraided promotion on social networking sites. The outcome of this stage is the empathy of the research gap and detailed explanation and reasoning of using the AIDA model. This study tried to provide enough awareness and understanding to the people associated with minor industries, how to utilize social networking sites as a promotion instrument strategically and these strategies based on the AIDA model. The second stage associated with the methodology applied i.e. focus-group discussions and interviews in person. The participants of the focus group and interviewees were approached to gather valuable information about social networking sites and strategies grounded on the AIDA model. The material gathered in stage two is vital for stage three where it works as an input to develop a plan for utilizing social networking sites as an instrument of promoting and advertising in small businesses (Table \#2).

\section{Research Analyses \& Discussions}

In stage two, the information gathered through discussions of focus-group and interviews. Participants for the focus groups and individual interviews were belonging to 40 cottage and small industry's owners, entrepreneurs and directors of the middlesized organizations.

Table \#2:

\begin{tabular}{|c|c|c|c|}
\hline Stages & $\begin{array}{l}\text { Model } \\
\text { used }\end{array}$ & Outcomes & $\begin{array}{l}\text { Research } \\
\text { Aims }\end{array}$ \\
\hline $\begin{array}{l}\text { Literature } \\
\text { analysis }\end{array}$ & & $\begin{array}{l}\text { Filling gap } \\
\text { and provide } \\
\text { reasoning o } \\
\text { using AIDA } \\
\text { model in } \\
\text { Pakistan }\end{array}$ & $\begin{array}{l}\text { Developing } \\
\text { strategy to } \\
\text { provide } \\
\text { awareness } \\
\text { for using } \\
\text { social } \\
\text { networking } \\
\text { sites as }\end{array}$ \\
\hline $\begin{array}{l}\text { Focus Group } \\
\text { Discussions } \\
\text { \& Personal } \\
\text { interviews }\end{array}$ & & $\begin{array}{l}\text { Strategy to } \\
\text { provide } \\
\text { awareness } \\
\text { for using }\end{array}$ & $\begin{array}{l}\text { marketing } \\
\text { instrument } \\
\text { with the } \\
\text { help of }\end{array}$ \\
\hline $\begin{array}{l}\text { Strategy } \\
\text { development }\end{array}$ & & $\begin{array}{l}\text { model on } \\
\text { social media } \\
\text { as } \\
\text { promotiona } \\
\text { instrument }\end{array}$ & $\begin{array}{l}\text { model in } \\
\text { Pakistan }\end{array}$ \\
\hline
\end{tabular}

Illustration\# 1: Research Outline

Source: Author

For various purposes focus group discussions have been used by the researchers in different of contexts and situations (Krueger \& Mary, 2009). For personal interviews, snow-ball and convenience methods were used in order to save time and cost. 


\section{Strategy Development:}

Now the third stage where the development of the strategy for minor businesses is the key aim. In order to use social media as a promotional and publicizing instrument, the analysis of literature and the information collected through focus-group and personal interviews, the strategy was developed. The strategy (which lies on the components of the AIDA model), helps and provides assistance to the minor business owners, entrepreneurs, etc. on how to utilize social sites strategically as an instrument for marketing. The AIDA model components which can be used for social networking are grasping attention, generate interest, instigate desire and finally enabled the customers in stimulating to take decisions in order to fulfill their desire.

\section{Research Instruments:}

The information gathered in focus group and personal interviews were on the basis of their experiences, perceptions, and understanding about using social networking sites as a promotional instrument. A guideline was provided to all participants of the focus group in order to carry on the discussion strictly systematically and manageable way. The experiences, understandings, and perceptions shared will answer the investigation queries and attained the objective framed. The rules for focus group and personal interviews were developed for utilizing social networking sites as a marketing instrument on two features i.e. on the profile of the participants and the strategy lied on the model of AIDA modules.

\section{Participant's Demographics Illustration:}

The 20 contributors of focus group and 100 individuals of personal interviews were mostly the entrepreneurs, owners of minor companies and directors of middle-sized organizations working at key managerial. Ages range to approx. in between $30-45$ years. For personal interviews, participants and focus group members were selected on the basis of their experiences and they were using social media for their businesses for not less than 3 years (Table\# 3).Individual interviews were also conducted from 30 participants who were not using social media. These participants were selected on the basis of running different minor businesses in varied areas of Sindh, Pakistan to inquire about the reasons for not using social networking sites to promote their businesses (Table\# 4).

Table \#3

\begin{tabular}{|c|c|c|c|c|}
\hline Age & $\begin{array}{l}\text { Participants associated to the types of } \\
\text { businesses }\end{array}$ & $\begin{array}{l}\text { Type of } \\
\text { organization }\end{array}$ & $\begin{array}{l}\text { Designations/ } \\
\text { positions }\end{array}$ & $\begin{array}{l}\text { Nor of years } \\
\text { of using } \\
\text { Social Media }\end{array}$ \\
\hline $\begin{array}{l}30-45 \\
\text { years }\end{array}$ & $\begin{array}{l}\text { Beauty accessories and fashion clothing, } \\
\text { beauty parlors, boutiques ( men, women } \\
\& \text { kids wear), , Denim jeans, sportswear } \\
\text { and accessories, baking, home cooking, } \\
\text { kitchen accessories, lingerie, school and } \\
\text { travelling bags. }\end{array}$ & Minor & $\begin{array}{l}\text { Owners of the } \\
\text { organizations, } \\
\text { Entrepreneurs, } \\
\text { Social Media } \\
\text { Specialists and } \\
\text { Directors etc. }\end{array}$ & 3-7 years \\
\hline
\end{tabular}

Demographics illustration of the participants

Source: Author

Table \#4

\begin{tabular}{lllll} 
Age & $\begin{array}{l}\text { Participants associated to the types of } \\
\text { businesses }\end{array}$ & $\begin{array}{l}\text { Type of } \\
\text { organization }\end{array}$ & $\begin{array}{l}\text { Designations/ } \\
\text { positions }\end{array}$ & $\begin{array}{l}\text { No. of years } \\
\text { of } \begin{array}{r}\text { using } \\
\text { Social Media }\end{array}\end{array}$ \\
\hline $30-45$ & $\begin{array}{l}\text { Beauty accessories and beauty parlors, } \\
\text { fast food stalls, fruits and vegetable shops, }\end{array}$ & Minor & $\begin{array}{l}\text { Owners of the } \\
\text { organizations, }\end{array}$ & None \\
years & $\begin{array}{l}\text { Tiffin service, , vehicle washing, tea } \\
\text { shops, mechanical works, Electronic } \\
\text { repairing services, Chat houses, bakeries, } \\
\text { pharmacy stores, tailor shops. }\end{array}$ & $\begin{array}{l}\text { Entrepreneurs, } \\
\text { Social Media }\end{array}$ & \\
\hline
\end{tabular}

Demographics illustration of the participants

Source: Author 


\section{Usage of business strategy on social networking sites:}

Nowadays it is easier to attract possible or retain current customers towards good products or services through lively marketing and promotional offers. These can be possible by utilizing social networking sites as the main channel of disseminating related information. Social media provides enough platforms to everyone who knows the magic of social media. These viewpoints shared by the focusgroup participants and individuals of personal interviews. They further added that there is a range of ways through which people can sell their services and goods very easily. The ways range from a traditional approach like through television, radio, newspapers, magazines, etc. and contemporary approach includes emails, websites and the usage of different social networking sites, etc. The participant working as Denim jeans retailer claimed that social networking in business generate trust and build brand awareness. "If we utilize the social media platform smartly we can easily capture the consumer's interests that will help in making brand popular", the other added.

The other participant further explained that there is no match of the level of awareness and understanding about brands and quality goods and services before and after the introduction of social media into the retail businesses. The level of awareness and understanding is much elevated and consumers and customers these days are now become very clever in choosing and purchasing any services or products. The other participant who is selling kids accessories and clothing via Facebook continues by saying that consumers now have many options like they have plenty of options available online and they can easily compare each item online as well as in shops too. One of the lady participants who sell home-made cakes and cupcakes via Facebook argued that "information about company, products or services, promotional offers, and prices need to be stated clearly on the company's websites or on social media ads so that customer will ascertain not only about the credibility of the company. However, they know more about the product and services."

The rest of the participants agreed on this note. Several participants suggested advertising newly goods or facilities immediately to build interest of the customers and once their interest is developed, many measures can be put in place to entertain them with some special discounts, and presale services. All participants agreed on making the ordering process simple and payment mode need to be easier and secured in order to encourage the customers to do hassle-free shopping online. They also recommended that it is of great need that social media give plenty of payment options to the customers so that they can easily purchase through their convenient mode of payment.

The summary of using social networking sites for strategic business marketing is given below Table \# 5;

Table \# 5: Amalgamation Process of Strategy for using Social Media as Promotion \& Marketing Instrument based on the Four AIDA modules:

\begin{tabular}{|c|c|}
\hline Attraction & $\begin{array}{l}\text { - Market the products or services on social networking sites such as } \\
\text { daraz.pk, } \quad \text { yayvo.com, sheops.com, } \\
\text { int.sentimentsexpress.com, www.aliexpress.com etc. } \\
\text { Follow and join as many social groups and companies on social } \\
\text { media } \\
\text { - Tag people, friends, contacts, etc. } \\
\text { - Create controversies of your products and services to grab attention } \\
\text { so that people talk about your company and products / services. } \\
\text { - Use referrals to reach public and potential buyers. } \\
\text { - } \quad \text { Cend emails and instant messages to cover large pool of people } \\
\text { (affiliate marketing) } \\
\text { Disseminate the highlighted features in such a way that customers } \\
\text { believe that it is a necessity. }\end{array}$ \\
\hline & - $\quad$ Put clear information need to be provided regarding products/ \\
\hline
\end{tabular}




\begin{tabular}{l}
\hline Services and company description and other key features, and \\
contact details etc. \\
Put catchy images with different angles of the products or services if \\
appropriate. \\
Update the websites information, images and promotional offers \\
timely \\
If anything new is coming, advertise and tweet everywhere on the \\
social media.
\end{tabular}

Source: Author

\subsection{Conclusion and Recommendations:}

The key focuses of this study is to develop and raise awareness about social networking sites and its strategic usage in order to provide both the experimental and conceptual perceptions among the people living in remote areas and are associated with minor businesses. In terms of the experiment, the suggested marketing strategy for social networking sites can be appropriate to minor industries in order to ensure that they will get effective and improvised outcomes. This study not only provides awareness but also enabled small business owners to apply the designed strategies for marketing their products and services. In this context, it also aids to ease the entrepreneurs as well to practice more effectively and efficiently in using social media as a mode of marketing and promotional strategies. This, in turn, can help the small business entrepreneurs to tremble hands with marketing strategies through novel media revolt. For small businesses and entrepreneurs, social media and the internet are becoming mandatory and unavoidable ingredients nowadays to sell and run businesses. It is also very crucial to be innovative, competitive and accept every challenge constantly to run businesses and maximize profits and these are the highlight of this research study.

The usage of social networking sites for strategic marketing is apparent and has a significantly optimistic impact on small business entrepreneurs and obliquely on financial and economic progression. Moreover, the research revealed that social media is the most budget operative in running businesses for all whoever wanted to enter into the mainstream of business regardless the size of their businesses. Therefore small business entrepreneurs get benefited with the use of marketing strategies on social media because it is easy to hit the targeted audiences anywhere in the world, simple to display ads with a minimal cost, instant way of reaching a large pool of potential customers, can influence customers to make purchasing decisions and is way ahead cost effective in comparison to traditional marketing and advertising. Hence in many ways it supports the previous studies, their outcomes and 
findings in using the social media for business purposes (Kirtis and Karahan, 2011; Birkner (2011; Hoek and Gendall (2003) and playing effective role in relationship marketing services and after-sale related issues as well.

In the conceptual context, this research extends the ways in order to provide awareness of applying the AIDA model strategically in small businesses through social sites for promotion and advertising. The outcome of this research exhibits that this model certainly be used pragmatically in strategizing marketing and advertising activities for small businesses and entrepreneurs and this can be done by utilizing social media. The outcomes support the studies and recommendations given by many researchers such as (Reyneke et al., 2011; Lagrosen 2005; Ashcroft and Hoey, 2001; Hoek and Gendall, 2003; and Woodcock and Green, 2010) and awareness to build a concept of digital marketing for effective utilization of social media (SMB Group, 2018). According to their investigation, the AIDA model and its components are helpful and have practical relevance in the context of their usage through social media. Some of them added that the computer interceded as instruments and have capabilities for becoming effective marketing operative weapon for the commercial companies.

Irrespective of the conclusions, the study has some recommendations as well. It is highly recommended that the government, social actors, political, influential and elected people of these remote areas need to exert their key focus toward increasing the literacy rate and education. Education will lift their awareness and consciousness are that help them avoid people who are buying their goods for nominal prices and resell them in the open and international markets at huge prices. Therefore proper counseling needs to be provided appropriately to the minor business owners so that they will utilize all the available means and medium to promote and market their products and services.

\subsection{Limitations of the study:}

During this current study, the author comes across several limitations, however, the biggest and worrisome is the illiteracy and absence of basic knowledge and awareness about the current businesses trends, scope, demand and usage of technology and social media strategically and its influential capabilities among the people who are associated with the cottage industries and minor businesses. Most of them do not even have the basic education and hardly attended any schools or high-schools. Therefore these people do not even know the exact worth of their products and merchandizers taking advantage of their illiteracy and lack of awareness and making huge profits and money for themselves only. However, if more studies would be conducted in the same perspective with different backgrounds and style then it will contribute greatly in order to educate people on utilizing social media strategically and with the amalgamation of AIDA model. Furthermore, it also helps them in providing awareness and countless insights of using social media strategically and the AIDA model as one of their core tools of marketing and advertises their products and services to flourish their minor businesses and make them fly to the zenith.

Further, it is also suggested that the developed strategy needs to be executed to examine the relevancy and applicability and more research studies are required to augment its applicability and relevancy in other topographical and ecological settings having the same kind of issues and problems. Furthermore, the prime focus of this study was on the AIDA model as a fundamental concept. Therefore focusing on other philosophies, concepts, models and theories for the purpose of marketing, goods and services can be considered for the dependability of the model and need to be enhanced further in the future.

\section{References:}

- Ashcroft, L. \& Hoey, C. (2001). PR, marketing and the Internet: Implications for information professionals. Library Management, 22 (1/2), 68-74.

- Berthon, P., Ewing, M.T., \& Napoli, J. (2008). Brand management in small to medium-sized enterprises. Journal of Small Business Management, 46 (1), 27-45.

- Birkner, C.(2011). Sharing the Love. Marketing News, 45(3), 11-12.

- Gilmore, A., Carson, D., \& Grant, K. (2001).SME marketing in practice. Marketing Intelligence \& Planning, 19 (1), 611. 
- Gilmore, A., Carson, D., O'Donnell, A., \& Cummins, D. (1999). Added value: A qualitative assessment of SME marketing. Irish marketing review, 12(1), 2735.

- Heath, R., \& Feldwick, P. (2007). Fifty years using the wrong model of advertising. International Journal of Market Research, 50 (1), 29-59.

- Hoek, J. \& Gendall, P. (2003). How Does Sponsorship Work? In the proceeding of the ANZMAC 2003, 1-3 December, 2003, Adelaide, pp. 9-16.

- Huang, X., \& Brown, A. (1999). An analysis and classification of problems in small business. International Small Business Journal, 18 (1), 73-85.

- Kaplan, A. M., \& Haenlein, M. (2010). Users of the world, unite! The challenges and lucre of social media. Business Horizons, 53 (1), 59-68.

- Keegan, S. (2009). Qualitative research: Good decision making through understanding people, cultures and markets. Kogan Page Publishers.

- Kim, A.J. \& Ko, E. (2011) Do social media marketing Activities ENHANCE customer equity? An empirical study of the luxury fashion brand. Journal of Business Research. $65,1480-1486$.

- Kirtis, A.K. \& Karahan, F.(2011) To be or not to be in Social Media arena as the most cost-efficient marketing strategy after the global recession. In the Proceding of Social and Behaviorial Sciences, pp. 260-268, $7^{\text {th }}$ International Strategic Management Conference.

- Khan, F. R., Hatami, Y., Sasidharan, A., \& Al-Roshdi, S. (2017). Investigative Study of Preferred Social Media Marketing in Safeer Mall, Sohar, Oman. Humanities $\mathcal{E}$ Social Science Reviews, 5(1), 53-63.

- Kojima, T., Kimura, T., Yamaji, M., \& Amasaka, K., (2010). Proposals and development of the direct mail method "PMCI-DM" for effectively attracting customers. International Journal of Management \& Information Systems, 14 (5), 15-21.

- Krueger, R. A. \& Mary, A. C. , 2009. Focus Groups: A Practical Guide for Applied
Research. 4 th ed. Thousand Oaks, CA: Sage.

- Lagrosen, S. (2005). Effects of the internet on the marketing communication of service to companies. Journal of Services Marketing. 19(2), 63-69.

- Mangold, W.G., \& Faulds, D.J. (2009).Social media: The new hybrid element of the promotion mix. Business Horizons, 52 (4), 357-365.

- Michaelson, D., \& Stacks, W. D. (2011). Standardization in public relations measurement and evaluation standardization. Public Relations Journal, $5(2)$, Spring.

- Morgan, L. D. (1996). Focus Groups. Annual Review of Sociology, 22(1), 129-52.

- Moss, D., Ashford, R., \& Shani, N. (2003). The forgotten sector: Uncovering the role of public relations in SMEs. Journal of Communication Management, 8 (2), 197-210.

- Reyneke, M., Pitt, L., \& Berthon, P.R. (2011) Luxury wine brand visibility in social media: An exploratory study. International Journal of Wine Business Research, 23 (1), 21-35.

- Rowley, J. (2002). Information Marketing in a digital world. Library Hi Tech, 20 (3), 52-58.

- Shahizan, H., Norshuhada, S., Norlaily, H., NL, Sobihatun, NAS, \& Mohd Samsu, S., (2012). Persuasive as Social Media Technology for Business: Trends and Perceived Impact in Malaysia. Sintok, Kedah: Universiti Utara Malaysia.

- Small Business Trends. (2011). "Small Business Survey by Deluxe reveals snapshot of the social media savvy Entrepreneurs". Retrieved from http://smallbiztrends.com/2011/06/soci al-media-savvyentrepreneurs.html

- Small Business Trends. (2018), Facebook Introduces Prime Time Anytime Offering Businesses More Training Free Retrieved from https://smallbiztrends.com/2018/04/fac ebook-prime-time-anytime.html

- Stelzner, M. A. (2010). 2013 Social media marketing industry report: How marketers are 
using social media to grow their businesses. SocialMediaExaminer. com.

- Stewart DW and Shamdasani PM (1990), Focus Groups: Theory and Practice. Newbury Park, CA: Sage.

- Stokes, D. (2000). Putting entrepreneurship into marketing. Journal of Research in Marketing E Entrepreneurship, 2 (1), 1-16.
- Taylor, C. (2011). Twitter has 100 million active users. Retrieved from Mashable. com

- Woodcock, N., \& Green, A. (2010). Social CRM as a business strategy, the customer framework. Retrieved from http://customerframework.com. 